\title{
Anatomy of a Project to Produce a First Nuclear Weapon
}

\author{
Robert Harney, ${ }^{1}$ Gerald Brown, ${ }^{2}$ Matthew Carlyle, ${ }^{2}$ \\ Eric Skroch, ${ }^{2}$ and Kevin Wood ${ }^{2}$
}

${ }^{1}$ Department of Systems Engineering, Naval Postgraduate School, Monterey, CA, USA

${ }^{2}$ Operations Research Department, Naval Postgraduate School, Monterey, CA, USA

We describe the industrial project that a "proliferator" would conduct to produce a first, small batch of nuclear weapons. From refining yellowcake ore to final weapons assembly, we highlight the project's tasks and their interactions. The proliferator can choose alternative production technologies that offer quicker completion, but at higher cost in terms of limited resources. The proliferator can also expedite his project by devoting more resources to critical tasks. From physics and chemistry, we determine raw material requirements. From industrial engineering and materials science, we convert these requirements into estimates of the time, manpower, energy, and money required to complete each task under normal and expedited conditions. Using generalized projectmanagement analysis tools, we then estimate the earliest possible completion time of the project, assuming two different levels of resource availability. We also estimate the time required to complete a weapon if some of the project's steps can be skipped; for example, if the proliferator acquires stolen, highly enriched uranium metal.

\section{INTRODUCTION}

This article documents the component tasks of a major industrial project that a "proliferator" must complete, or may need to complete, to produce "a first nuclear weapon." By this last phrase, we mean a first small batch of crude nuclear weapons. We integrate details from physics, chemistry, industrial engineering, and materials science to create a generalized critical-path network model of the project. ${ }^{1}$ We also derive estimates of raw-material, manpower, energy, and

Received 30 January 2006; accepted 15 March 2006.

For sustained research support, the authors thank the Air Force Office of Scientific Research, and the Office of Naval Research.

Address correspondence to Robert C. Harney, Associate Professor, Department of Systems Engineering, Naval Postgraduate School, Monterey, CA 93943, USA. E-mail: harney@nps.edu 


\section{Harney et al.}

time requirements for task completions under normal or expedited conditions. With this information and the model, we then show how to estimate the earliest possible completion time for such a project given different assumed levels of resources. An extended model in a follow-on article ${ }^{2}$ shows how one might delay the project's overall completion time by disrupting certain tasks through, for example, embargoes on key materials. The current article should provide policymakers with a sound quantitative basis for devising technologically oriented policies regarding nonproliferation. ${ }^{3}$

The details of the proliferator's nuclear-weapons program depend on too many factors to consider in a single article, so we make the following simplifying assumptions in a case study: (a) The program is covert, (b) the proliferator already produces yellowcake uranium for use in civilian reactors or for sale to others, (c) he will pursue a simple fission weapon, and (d) he has signed the Non-Proliferation Treaty (NPT).

A nuclear-weapons program is complex, but the basics of nuclear-weapon design are now well known and publicly available: 4 The acquisition of weaponsgrade uranium or plutonium is the proliferator's main hurdle to creating a nuclear weapon, not theoretical physics. But, (a) neither uranium nor plutonium are available on the open market, (b) NPT inspections preclude the reprocessing of spent nuclear fuel into weapons-grade plutonium, and (c) we shall initially assume that stolen materials are unavailable. Consequently, the key to creating a nuclear weapon covertly will be the proliferator's development of an organic manufacturing infrastructure for weapons-grade uranium and/or plutonium. A plutonium-based weapon would require the covert construction of a nuclear reactor, and plutonium is difficult to handle, so it is reasonable to assume that the proliferator would choose a simpler, uranium-based weapon. Yellowcake uranium oxide, diverted from civilian use, will constitute the raw material. (For context, see Spears $^{5}$ who traces the lifecycle of nuclear materials from raw ore to waste disposal.)

Yellowcake can be diverted from civilian use even if the proliferator does not operate a nuclear fuel cycle. For example, controlling a uranium mine suffices because yellowcake can be diverted from the ore-processing facilities near such a mine. More than 30 countries have proven uranium reserves, and surely others have uranium-ore deposits that have not been discovered, or at least not reported. Uranium oxide can also be extracted from certain ores that are sold in international commerce for their scandium, vanadium, or other metal content. This offers another means to obtain yellowcake, or a substitute for it, without operating a nuclear fuel cycle.

The proliferator will need to commit a great deal of material, manpower, and technology to all parts of his nuclear-weapons project, from constructing manufacturing infrastructure for uranium metal, to the acquisition of a weapons-delivery method, for example ballistic missiles. Managing such a complex and expensive project is difficult without some sort of project-management 
protocol, especially if the project is to remain covert. Since the late $1950 \mathrm{~s}$, governments and industry have widely employed techniques of operations research to the scheduling and coordination of complex projects. In particular, the basic methods of the Program Evaluation Review Technique/Critical Path Method (PERT/CPM) have been extended over the years to manage the complexities that arise in real-world projects. ${ }^{6}$

Moder, Phillips, and Davis define a project as "a set of tasks or activities related to the achievement of some planned objective, normally where the objective is unique or non-repetitive."7 The proliferator's program to develop a first nuclear weapon fits this definition well. We can therefore reasonably expect him to employ standard project-management tools such as Microsoft Project to plan, organize, and schedule the project's tasks efficiently. ${ }^{8}$ In any case, we will use these tools to estimate the project's completion time, and should the proliferator choose to act suboptimally by not using such tools, the resulting estimate will be appropriately conservative for our purposes. That is, the project will take longer to complete than we estimate.

Project-management models are universally represented as networks. In the now-standard activity-on-node version of a project network, nodes represent important (sub)tasks that must be completed to finish the project, whereas arcs represent precedence relationships between tasks. In the basic model, a task- $i$ node is connected to a task- $j$ node with a directed arc $(i, j)$ if task $i$ must be completed before task $j$ is begun. Each node $i$ possesses a "length" that represents task $i$ 's nominal duration; arcs have zero length. The overall duration of the project, from an artificial "start task" to an artificial "finish task," is the total length of the longest, directed path through the network, also known as the critical path.

We must generalize the basic project model, as follows:

1. Completion of any task in a "normal" amount of time consumes a fixed amount of one or more resources that are in limited supply. ${ }^{9}$ In particular, we model consumption of energy, raw materials, and three types of manpower, and through these, the consumption of money.

2. The duration of an individual task may be expedited, that is, shortened, by allocation of additional quantities of required resources. ${ }^{10,11}$ We assume a linear relationship between the amount of each additional resource provided and the duration of the task: More resources accelerate progress. However, each task requires some minimum amount of time to complete, below which additional resources have no effect.

3. When one or more tasks are expedited to minimize project completion time, the project has been "crashed." Crashing is limited by resource availability, including a monetary budget. 


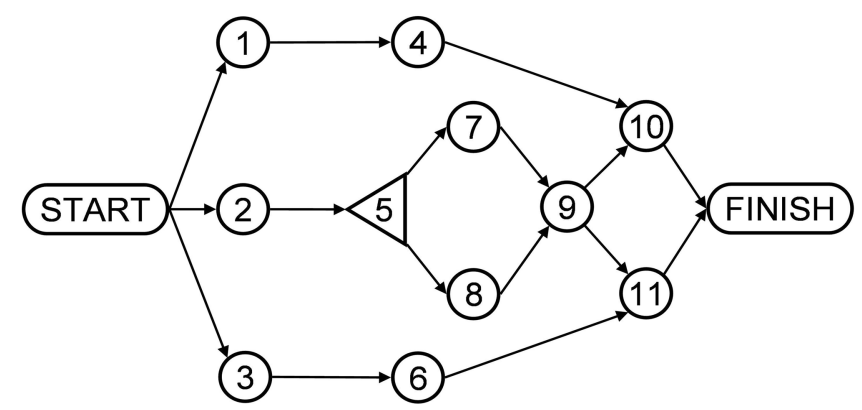

Figure 1: An activity-on-node project network with one decision node. Tasks represented by nodes 1 through 6, and 9 through 11, must be completed to complete the project. A triangular node represents a "decision task" 14: After Task 5 is complete, either Task 7 or Task 8 must be completed. Arcs represent precedence relationships.

4. Standard finish-to-start (FS) precedence relationships between pairs of tasks are generalized to include start-to-start (SS), finish-to-finish (FF), or start-to-finish (SF). Given this generality, it is easy to accommodate a lagor lead-time between pairs of tasks. ${ }^{12}$

5. Certain milestone events, most importantly the stockpiling of adequate supplies of highly enriched uranium metal (HEU), can be achieved via alternative courses of action. When one such alternative is chosen, the tasks in the other alternative(s) need not be completed. Alternative courses of action diverge at decision nodes $;{ }^{13}$ see Figure 1 . In our case study, the decision node chooses one of three uranium-enrichment technologies.

Within the limits of his resources, the proliferator wishes to minimize the completion time of his weapons project, that is, crash the project, by expediting "critical tasks" (i.e., tasks on the critical path), and tasks that become critical as other task durations are reduced.

\section{ASSUMPTIONS}

Given the proliferator's goal of completing a first weapon as soon as possible, we assume he will pursue a gun-type fission weapon, the same design used in the "Little Boy" bomb dropped on Hiroshima, Japan in 1945. That design is simple but reliable: Little Boy was relatively crude, but its designers were so confident that Hiroshima was its first full-scale test. ${ }^{15}$ The gun-type weapon requires more HEU than the alternative, an implosion weapon, but the latter design would require high-visibility, high-energy testing to ensure its reliability and it seems likely that a covert proliferator would prefer to avoid such testing.

"The first nuclear weapon" will really be a small number of weapons, the most that can be manufactured without undue risk of detection. We assume a production of six weapons per year, which we estimate will require an annual input of 300 kilograms (kg) of HEU. In turn, this will require the inputs 
estimated by the chemistry of Appendices A and B, which include about 120 metric tons of yellowcake each year.

The main tasks in the project are:

1. Covert diversion of 120 metric tons of yellowcake annually (this quantity amounts to only one medium truckload per month, is likely to go undetected, and is the key reason for assuming a production of at most six weapons per year);

2. Production of enrichment-plant feed material (uranium hexafluoride, $U F_{6}$ ) from yellowcake;

3. Uranium enrichment, including the choice of method to employ;

4. Conversion of highly enriched $U F_{6}$ to HEU metal; and

5. Design and construction of the actual weapons.

Appendix $\mathrm{C}$ displays the tasks included in our case study, and the Gantt chart in Figure 2 shows a small part of a complete production plan from that study.

We assess the requirements for specialized equipment from the chemical processes described in Appendix A. The project network comprises

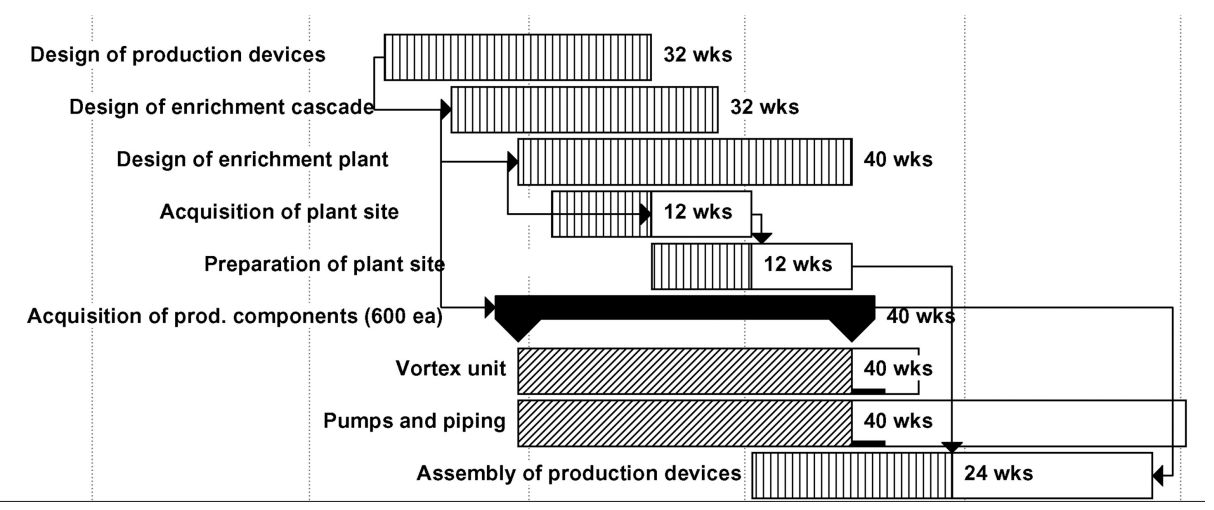

Figure 2: Gantt chart, from Microsoft Project, depicting 9 out of about 200 tasks in the case-study project. (Created using Microsoft Project.) The solid horizontal bar for "Acquisition of production components" indicates a summary task. (A "summary task" is a feature of Microsoft Project, not a fundamental component of a standard project network.) This summary task comprises two (sub)tasks, the acquisition of a "Vortex unit" and of "Pumps and piping." The "forward" hashing on their corresponding bars indicates that they do not lie on the critical path. The task "Acquisition of plant site" is represented by two adjacent bars. The first bars "backward" hashing indicates that this task is critical, and its left and right endpoints represent the tasks planned, expedited start and completion dates, respectively. The tasks planned duration of 12 weeks is displayed to the right of the first bar. The second bars vertical hashing signals that the task has been expedited by an amount proportional to the bars length, which also happens to be 12 weeks. (The nominal, unexpedited duration of this task is 24 weeks.) The figure uses arrows to indicate precedence relationships between tasks. For example, there is an "SS" (start-to-start) relationship, including an 8-week lag, between "Design of production devices" and "Design of enrichment cascade." 
Table 1: Efficiency of uranium-enrichment technologies.

\begin{tabular}{lcccc} 
Technology & $\begin{array}{c}\text { Separation } \\
\text { factor }\end{array}$ & $\begin{array}{c}\text { Number of stages } \\
\text { for } \mathbf{9 0 \%} \text { HEU }\end{array}$ & kWh/SWU & $\begin{array}{c}\text { Kilowatts for } \\
\mathbf{6 0 , 0 0 0 ~ S W U / Y r}\end{array}$ \\
\hline Gaseous diffusion & $1.0040-1.0045$ & $3,500-4,000$ & 2,500 & 17,120 \\
Gas centrifuge & $1.2-1.5$ & $40-90$ & $100-200$ & $685-1,370$ \\
Aerodynamic & $1.015-1.030$ & $540-1100$ & $3,600-4,000$ & $24,660-27,400$ \\
\hline
\end{tabular}

Regardless of the technology used, producing HEU from natural uranium requires multiple equipment stages arranged in a progressive enrichment cascade. The separation factor is the ratio of the relative enrichment $\left(U_{235}\right.$ to $\left.U_{238}\right)$ of the concentrated product to that of the depleted tails in the output of any single stage of the cascade. The number of stages required to produce HEU assumes the final tails contain less than $0.3 \% U_{235}$. "kWh per SWU" measures the kilowatt-hours of energy required to produce approximately 5 grams of HEU. The final column gives the average power consumption (rate) of an enrichment cascade producing about $300 \mathrm{~kg}$ of HEU a year. Source: U.S. Congress, Office of Technology Assessment (OTA), 1993. "Technologies Underlying Weapons of Mass Destruction," OTA-BP-ISC-115, U.S. Government Printing Office, December, p. 143.

approximately 200 tasks (nodes) and 600 precedence relationships (arcs). The proliferator must manage five key resources in addition to money: energy, materials, professional labor (e.g., scientists and engineers), skilled labor (e.g., machinists), and unskilled labor.

If the proliferator chooses to expedite a given task, he must expend more of each resource required for that task. The amount of resource $r$ consumed, given task duration $T$, is assumed to be $b_{r}\left(1+\left(a_{r}-1\right)(\bar{T}-T) /(\bar{T}-\underline{T})\right)$, where $\bar{T}$ denotes the task's nominal duration, $\underline{T}$ denotes its minimum duration, $T$ must satisfy $\underline{T} \leq T \leq \bar{T}, b_{r}$ is the nominal consumption of that resource (i.e., when the task's duration is $\bar{T}$ ), and $a_{r}$ is an "acceleration factor" that depends only on the resource. See Appendix $\mathrm{C}$ for the values of $\bar{T}$ and $\underline{T}$ used in the case study; Table 2 lists the acceleration factors.

The proliferator can choose one of any number of enrichment technologies to pursue: In our case study his options are gas centrifuges, gaseous diffusion, or aerodynamic enrichment. Other enrichment technologies exist, but they are expensive and/or technically demanding, and therefore seem unlikely options. ${ }^{16}$ However, any optional enrichment technique can be modeled with our methods. Table 1 shows how to estimate the required number of enrichment machines

Table 2: Acceleration factors for the five non-monetary resources tracked in our case study.

\begin{tabular}{lc}
\hline Resource & Acceleration Factor \\
\hline Energy & 2.0 \\
Professional labor & 1.2 \\
Skilled labor & 1.5 \\
Unskilled labor & 2.0 \\
Materials & 1.2 \\
\hline
\end{tabular}

Each value is a multiplicative factor on total resource consumption for the fastest possible completion time of any task. For example, if 10 professional laborers are needed to complete a task its nominal time $\bar{T}$, then it would require 12 professional laborers $(12=1.2 \times 10)$ to complete the task in the shortest possible time $\underline{I}$. 
Table 3: National cost and availability of resources in our case study. The project is further constrained by a budget of $\$ 190$ million.

\begin{tabular}{llrr}
\hline Name & Units & Unit cost $\mathbf{( \$ / \text { Unit) }}$ & Units available \\
\hline Energy & MWhr & 100 & $3,100,000$ \\
Materials & $\$ K$ & 1,000 & 190,000 \\
Professional labor & Mmo & 48,000 & 10,000 \\
Skilled labor & Mmo & 24,000 & 10,000 \\
Unskilled labor & Mmo & 6,000 & 6,000 \\
\hline
\end{tabular}

$\mathrm{MWhr}=$ megawatt-hours. Mmo = man-months

and the energy consumption for each technology. A separative work unit (SWU) measures the effort required to separate $U_{235}$ and $U_{238}$ isotopes during enrichment. Production of $1 \mathrm{~kg}$ of HEU from natural uranium requires approximately 200 SWUs, and therefore anywhere from 570 to 23,000 kilowatts of power, depending on the technology used. ${ }^{17}$ Appendix $\mathrm{C}$ lists case-study data, including nominal costs.

\section{RESULTS AND CONCLUSIONS}

Using the amounts of energy, materials, manpower, and labor listed in Table 3, and a budget of $\$ 190$ million, the proliferator uses aerodynamic enrichment to complete his project in 338 weeks (six and a half years).

If all resource availability is doubled, including that for dollars, crashing allows the proliferator to complete the project in 260 weeks (just under 5 years).

If we relax our initial assumption that stolen HEU is unavailable, and suppose the proliferator obtains $300 \mathrm{~kg}$ of stolen HEU directly from a third party, we have a scenario viewed by some as nearly equivalent to having a deliverable weapon. ${ }^{18}$ Our model, appropriately modified and using nominal resource levels, shows that the proliferator will still need 208 weeks (4 years) to complete a first batch of 6 weapons. (With no organic source of HEU, that may also be the only batch of weapons he will ever be able to produce.) If the proliferator has access to unenriched uranium hexafluoride $\left(U F_{6}\right)$, and has also developed a prototypic gas-centrifuge process (as Iran has), the model predicts that he will remain committed to gas-centrifuge enrichment, and will need an additional 216 weeks to complete his first weapon.

Even with $300 \mathrm{~kg}$ of HEU, the proliferator could be delayed in completing his project by limiting access to certain manufacturing components. "Acquire hafnia crucibles," task 127, is not a critical task-we estimate 24 weeks of slack here-but if we could delay this task in excess of 24 weeks, by any means, then we could delay a finished weapon by that excess. Furthermore, an instance of this task occurs in all alternative enrichment technologies, so the proliferator cannot avoid this delay by switching technologies. 
The International Atomic Energy Agency ${ }^{19}$ has recently declared that more than 40 countries do not fully comply with the NPT, and lists several nations that are capable of, or are suspected of engaging in, nuclear-weapons development. This article has shown how any one of them could proceed in this development.

\section{NOTES AND REFERENCES}

1. Chapter 1 of this book provides a good overview of this topic: J. J. Moder, C. R. Phillips, and E. W. Davis, Project Management with CPM, PERT and Precedence Diagramming, 3rd ed. (Van Nostrand Reinhold Company Inc., New York, 1983)

2. G. Brown, M. Carlyle, R. Harney, E. Skroch, and K. Wood, 2006. "Interdicting a nuclear weapons project," Technical Report NPS-OR-06-003, Naval Postgraduate School, Monterey, CA.

3. We find many books, papers, and reports that promote technology-based policies for nonproliferation, but, typically, the analysis of that technology is limited. For example, see: G. Perkovich, J. T. Mathews, J. Cirincione, R. Gottemoeller, and J. Wolfsthal, Universal Compliance: A Strategy for Nuclear Security (Carnegie Endowment for International Peace, 2005), J. Spector, "Strategic Planning for U.S. Nonproliferation Initiatives in Russia," in Occasional Paper No. 6, WMD Threats 2001: Critical Choices for the Bush Administration, M. Marletta, ed. (Monterey Institute of International Studies, 2001) 3840; Counterproliferation Program Review Committee, 1997. "Report on Activities and Programs for Countering Proliferation and NBC Terrorism," Report Number A468823, U.S. Congress, Washington, DC, May.

4. In fact, many of the details from the early weapons programs in the United States and elsewhere have been declassified and appear in the open literature; see: U.S. Department of Energy, Office of Declassification, 2001. "Restricted Data Declassification Decisions 1946 to the Present," (RDD-7), January 1, 2001.

5. D. Spears, ed., "Technology R\&D for arms control," Arms Control and Nonproliferation Technologies (Lawrence Livermore National Laboratory, Spring 2001).

6. D. G. Malcolm, J. H. Roseboom, C. E. Clark, and W. Fazar, "Application of a technique for research and development program evaluation," Operations Research, 7 (1959): 646669.

7. Moder, Phillips, and Davis, op. cit., 3.

8. Microsoft Corporation, 2004. "Microsoft Office." http://office.microsoft.com/home/ office.aspx?assetid=FX01085795, 10 February, 2004.

9. D. G. Malcolm, J. H. Roseboom, C. E. Clark, and W. Fazar, op. cit.

10. See this article and its references: J. E. Kelley, Jr., "Critical path planning and scheduling: Mathematical basis," Operations Research, 9 (1961): 296-320.

11. A. Charnes and W. W. Cooper, "A network interpretation and a directed subdual algorithm for critical path scheduling," Journal of Industrial Engineering, 13 (1961): 213-218.

12. Early work on project networks required that a "successor task" not begin until after all its "predecessor tasks" had been completed; for example, see: D. G. Malcolm, J. H. Roseboom, C. E. Clark, and W. Fazar, op. cit. This was later generalized in a model called "precedence diagramming" that permits every combination of pairwise partial 
orders between the start or finish of a predecessor-task and those of a successor-task; for example, see: Moder, Phillips, and Davis 1983, op. cit., chapter 4.

13. W. Crowston and G. L. Thompson, "Decision CPM: A method for simultaneous planning, scheduling, and control of projects," Operations Research, 15 (1967): 407-426.

14. Ibid.

15. For example, see: R. Rhodes, The Making of the Atomic Bomb (Simon \& Schuster Inc., New York, 1986) and R. Rhodes, Dark Sun: The Making of the Hydrogen Bomb (Simon \& Schuster Inc., New York, 1995).

16. M. Benedict, T. H. Pigford, and H. W. Levi, Nuclear Chemical Engineering, 2nd ed. (McGraw Hill, Boston, MA, 1985) chapter 14.

17. Nonproliferation Policy Education Center (NPEC), "Iran: Breaking Out Without Quite Breaking the Rules?" http://www.npec-web.org/projects/iranswu2.htm, 30 April 2004.

18. For example, see: C. D. Ferguson, 2004, "Can Bush or Kerry prevent nuclear terrorism," Arms Control Today, 34 (7): 13, 3 pgs.

19. International Atomic Energy Agency, 2004. Annual Report, http://www.iaea.org/ Publications/Reports/Anrep2003/index.html, 6 October, 2004.

\section{APPENDIX A. URANIUM-ENRICHMENT CHEMISTRY}

We study these chemical processes to deduce the facilities and equipment required to produce enriched uranium metal from yellowcake. The numbers beneath the chemical reaction formulas are molecular weights.

Source: For example, see M. Benedict, T. Pigford, and H. Levi, 1981. Nuclear Chemical Engineering, 2nd ed. (McGraw-Hill, New York), 129-160.

\section{Feedstock Preparation (Yellowcake to Uranium Hexafluoride)}

Stainless steel vessel (dissolution of yellowcake in nitric acid):

$$
\begin{aligned}
\mathrm{U}_{3} \mathrm{O}_{8}+6 \mathrm{HNO}_{3} & \rightarrow 3 \mathrm{UO}_{2}\left(\mathrm{NO}_{3}\right)_{2}+2 \mathrm{H}_{2} \mathrm{O}+\mathrm{H}_{2} \\
842+6 \times 63 & =3 \times 394+2 \times 18+2
\end{aligned}
$$

Stainless steel boiler (boil down of nitrate solution):

$$
\begin{gathered}
\mathrm{UO}_{2}\left(\mathrm{NO}_{3}\right)_{2}+6 \mathrm{H}_{2} \mathrm{O} \stackrel{\text { boil }}{\longrightarrow} \mathrm{UO}_{2}\left(\mathrm{NO}_{3}\right)_{2}^{*} 6 \mathrm{H}_{2} \mathrm{O} \\
394+6 \times 18=502
\end{gathered}
$$

High-temperature stainless steel boiler (thermal decomposition of nitrate into uranium trioxide):

$$
\begin{gathered}
\mathrm{UO}_{2}\left(\mathrm{NO}_{3}\right)^{2^{*}} 6 \mathrm{H}_{2} \mathrm{O} \stackrel{300^{\circ} \mathrm{C}}{\longrightarrow} \mathrm{UO}_{3}+6 \mathrm{H}_{2} \mathrm{O}+2 \mathrm{NO}_{\mathrm{x}} \\
502=286+6 \times 18+108
\end{gathered}
$$


Gas-solid reactor vessel (reduction of uranium trioxide to uranium dioxide):

$$
\begin{aligned}
& \mathrm{UO}_{3}+\mathrm{H}_{2} \stackrel{650^{\circ}-800^{\circ} \mathrm{C}}{\longrightarrow} \mathrm{UO}_{2}+\mathrm{H}_{2} \mathrm{O} \text { or } 3 \mathrm{UO}_{3}+2 \mathrm{NH}_{3} \\
& \quad \stackrel{650^{\circ}-800^{\circ} \mathrm{C}}{\longrightarrow} 3 \mathrm{UO}_{2}+\mathrm{N}_{2}+3 \mathrm{H}_{2} \mathrm{O} \\
& \quad 286+2=270+18 \text { or } 3 \times 286+2 \times 17=3 \times 270+28+3 \times 18
\end{aligned}
$$

Stainless steel reaction vessel (use hydrogen fluoride to convert uranium dioxide into uranium tetrafluoride):

$$
\begin{gathered}
\mathrm{UO}_{2}+4 \mathrm{HF} \stackrel{300^{\circ}-500^{\circ} \mathrm{C}}{\longrightarrow} \mathrm{UF}_{4}+2 \mathrm{H}_{2} \mathrm{O} \\
270+4 \times 20=314+2 \times 18
\end{gathered}
$$

Ultrahigh-temperature gas-solid reactor vessel (production of uranium hexafluoride gas):

$$
\begin{gathered}
\mathrm{UF}_{4}+\mathrm{F}_{2} \stackrel{1700^{\circ}-1800^{\circ} \mathrm{C}}{\longrightarrow} U F_{6} \\
314+38=352
\end{gathered}
$$

\section{Conversion of Uranium Hexafluoride to Uranium metal}

Gas-phase reactor with particulate separation; uranium hexafluoride to uranium fluoride solid:

$$
\begin{gathered}
\mathrm{UF}_{6}+\mathrm{H}_{2} \stackrel{375^{\circ} \mathrm{C}}{\longrightarrow} \mathrm{UF}_{4}+2 \mathrm{HF} \\
352+2=314+2 \times 20
\end{gathered}
$$

High-temperature metallurgical furnace; uranium fluoride to liquid uranium to be cast into weapon components:

$$
\begin{array}{lll}
\mathrm{UF}_{4}+2 \mathrm{Ca} \stackrel{\text { low heat }}{\longrightarrow} \mathrm{U}+2 \mathrm{CaF}_{2} & \text { or } & \mathrm{UF}_{4}+2 \mathrm{Mg} \stackrel{550^{\circ}-700^{\circ} \mathrm{C}}{\longrightarrow} \mathrm{U}+2 \mathrm{MgF}_{2} \\
314+2 \times 40=238+2 \times 78 & \text { or } & 314+2 \times 24.3=238+2 \times 62.3
\end{array}
$$

\section{APPENDIX B. CALCULATION OF RAW-MATERIAL REQUIREMENTS FOR SIX GUN-TYPE FISSION WEAPONS}

This appendix assesses the quantity of key raw materials required to produce six fission weapons, each of which requires $50 \mathrm{~kg}$ of HEU. Theoretical requirements are computed from the chemical reactions and molecular weights specified in Appendix A. We show inputs needed to create one kilogram of each intermediate material or one kilogram of the final HEU metal. The reader can then easily compute the theoretical requirements to manufacture the full $300 \mathrm{~kg}$ 
of HEU. However, our final values multiply the theoretical requirements by 1.5 to account for imperfect conversions in real-world industrial processes.

Source: the authors.

$1 \mathrm{~kg}$ of UNH(uranyl nitrate hexahydrate) requires $0.559 \mathrm{~kg}$ yellowcake and $0.251 \mathrm{~kg} \mathrm{HNO}_{3}$

$1 \mathrm{~kg} \mathrm{UO}$ requires $1.755 \mathrm{~kg}$ of $\mathrm{UNH}$

$1 \mathrm{~kg} \mathrm{UO}{ }_{2}$ requires $1.059 \mathrm{kgUO}_{3}$ and $0.0074 \mathrm{~kg} \mathrm{H}$

(hydrogen is ubiquitous, so we do not computed its final consumption)

$1 \mathrm{~kg} \mathrm{UF} 4$ requires $0.860 \mathrm{~kg} \mathrm{\textrm {UO } _ { 2 }}$ and $0.255 \mathrm{~kg} \mathrm{HF}$

$1 \mathrm{~kg} \mathrm{UF}_{6}$ requires $0.892 \mathrm{~kg} \mathrm{UF}_{4}$ and $0.108 \mathrm{~kg} \mathrm{~F}_{2}$

$1 \mathrm{~kg} \mathrm{HEUF}_{6}$ requires $232 \mathrm{~kg} \mathrm{UF}_{6}$

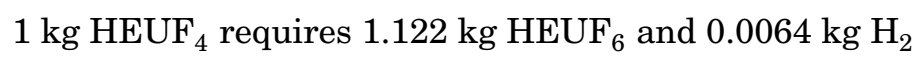

$1 \mathrm{~kg} \mathrm{HEU} \mathrm{metal} \mathrm{requires} 1.302 \mathrm{~kg} \mathrm{HEUF}$, and $0.336 \mathrm{~kg} \mathrm{Ca}$ or $0.204 \mathrm{~kg} \mathrm{Mg}$

Each weapon requires $50 \mathrm{~kg} 93 \%$ HEU metal, so six weapons require $300 \mathrm{~kg}$ HEU metal.

Using the theoretical conversion listed earlier, and multiplying by 1.5 to account for imperfect production processes, we estimate that $300 \mathrm{~kg}$ HEU requires:

$120,000 \mathrm{~kg}$ yellowcake

$54,000 \mathrm{~kg} \mathrm{HNO}_{3}$

$35,000 \mathrm{~kg} \mathrm{HF}$

$16,500 \mathrm{~kg} \mathrm{~F}{ }_{2}$

$150 \mathrm{~kg}$ Ca or $90 \mathrm{~kg} \mathrm{Mg}$

These numbers are assumed when making the estimates in Appendix C.

\section{APPENDIX C. TASKS INVOLVED IN A NUCLEAR WEAPONS PROGRAM}

The data described here reflect standard engineering analyses, and are based on one author's experience in weapon-systems development and production. However, we have made no attempt to obtain actual costs from vendors or to extract detailed development-and-production data from specific programs; such data would almost certainly be classified or proprietary. Consequently, individual cost estimates may be accurate only to within a factor of two, up or down. 


\section{Harney et al.}

A bold task name indicates a summary task, which is feature of Microsoft Project, not a standard component of a project network. (Note: For technical reasons, summary tasks are split into "summary-task start" and "summarytask finish.") "Task" 28 is the decision node: Exactly one course of action must be chosen at this point. A component name by itself, for example, "Stainless steel boiler," implies that the corresponding task is "acquire this component." Column 1 gives task identifier or "ID"; column 2 gives the task's name; column 3 is a "Code" not used in this article; column 4 gives the nominal task duration in weeks (wks); column 5 gives the minimum task duration if additional resources are applied; column 6 gives the task's direct predecessors, which must be completed before the task can commence ("FS," "FF", and "SS" denote finish-to-start, finish-to-finish and start-to-start precedence relationships, respectively. Each such relationship can have a lead $(-)$ or lag $(+)$, measured in weeks, associated with it. For instance "7SS +24 " in row 9 indicates that task 8 cannot begin until 24 weeks after task 7 begins); column 7 specifies the energy, in megawatthours (MWhr), required to complete the task; column 8 specifies the millions of dollars (\$M) in materials required to complete the task; column 9 gives the manmonths $(\mathrm{mm})$ of professional labor required to complete the project; columns 10 and 11 are similar, but for skilled labor and unskilled labor, respectively. 


\begin{tabular}{|c|c|c|c|c|c|c|c|c|c|c|}
\hline ID & Name & Code & $\begin{array}{l}\text { Normal } \\
\text { duration } \\
\text { (wks) }\end{array}$ & $\begin{array}{l}\text { Crashed } \\
\text { duration } \\
\text { (wks) }\end{array}$ & Predecessors & $\begin{array}{l}\text { Energy } \\
\text { (MWhr) }\end{array}$ & $\begin{array}{l}\text { Materials } \\
\text { (\$M) }\end{array}$ & $\begin{array}{l}\text { Professional } \\
\text { labor } \\
(\mathrm{mm})\end{array}$ & $\begin{array}{l}\text { Skilled } \\
\text { labor } \\
(\mathrm{mm})\end{array}$ & $\begin{array}{l}\text { Unskilled } \\
\text { labor } \\
(\mathrm{mm})\end{array}$ \\
\hline$\overline{1}_{\mathrm{s}}$ & $\begin{array}{l}\text { Nuclear Weapons Program [start] (tasks } \\
\left.2_{s}-177_{f}\right)\end{array}$ & - & - & - & None & - & - & - & - & - \\
\hline $2 s$ & $\begin{array}{l}\text { Diversion of commercial yellowcake } \\
\text { [start] (tasks 3-5) }\end{array}$ & - & $1_{S}$ & - & - & - & - & - & - & - \\
\hline 3 & Design yellowcake plant modifications & $\mathrm{Fb}$ & 48 & 24 & $2_{s}$ & 2.4 & 0.01 & 6 & 6 & - \\
\hline $\begin{array}{l}4 \\
5\end{array}$ & $\begin{array}{l}\text { Modify yellowcake plant } \\
\text { Divert yellowcake }\end{array}$ & $\begin{array}{l}\text { FC } \\
\text { LC }\end{array}$ & $\begin{array}{r}48 \\
120\end{array}$ & $\begin{array}{l}24 \\
60\end{array}$ & $\begin{array}{l}3 \\
4\end{array}$ & - & $\begin{array}{ll}0.1 \\
45\end{array}$ & $\begin{array}{r}6 \\
48\end{array}$ & $\begin{array}{r}6 \\
48\end{array}$ & 12 \\
\hline $2 f$ & $\begin{array}{l}\text { Diversion of commercial yellowcake } \\
\text { [finish] }\end{array}$ & - & - & - & 5 & - & - & - & - & - \\
\hline$b_{s}$ & $\begin{array}{l}\text { Produce enrichment plant feed material } \\
\text { [start] (uranium hexafluoride, UF6, tasks } \\
7-10,25,26 \text { ) }\end{array}$ & - & - & - & $1_{\mathrm{s}}$ & - & - & - & - & - \\
\hline 7 & Design fluoridation plant (FP) & $\mathrm{lb}$ & 80 & 40 & $b_{s}$ & 20 & 0.13 & 50 & 50 & - \\
\hline 8 & Acquire FP site & $\mathrm{Ca}$ & 24 & 12 & $7 S S+24$ & 0.6 & 0.15 & 3 & - & - \\
\hline 9 & Prepare FP site (internal modifications) & $\mathrm{Cc}$ & 24 & 12 & 8 & 6.6 & 0.07 & 3 & 15 & 15 \\
\hline$b_{s}$ & $\begin{array}{l}\text { Produce enrichment plant feed material } \\
\text { [finish] }\end{array}$ & - & - & - & $1_{\mathrm{s}}$ & & & & & \\
\hline $10_{s}$ & $\begin{array}{l}\text { Acquire FP components [start] (tasks } \\
11-24)\end{array}$ & - & - & - & $7 S S+12$ & - & - & - & - & - \\
\hline 11 & Stainless steel mixing vessel & $\mathrm{Ha}$ & 72 & 36 & $10_{s}$ & 1.8 & 0.03 & - & 9 & - \\
\hline 12 & Distilled water system & $\mathrm{Ha}$ & 72 & 36 & $10_{s}$ & 1.8 & 0.03 & - & 9 & - \\
\hline 13 & Nitric acid storage tank & $\mathrm{Ha}$ & 72 & 36 & $10_{s}$ & 1.8 & 0.1 & - & 9 & - \\
\hline 14 & Stainless steel boiler & $\mathrm{Ha}$ & 72 & 36 & $10_{s}$ & 1.8 & 0.1 & - & 9 & - \\
\hline 15 & Thermal decomposition vessel & $\mathrm{Ha}$ & 72 & 36 & $10_{s}$ & 1.8 & 0.25 & - & 9 & - \\
\hline 16 & Drying kiln & $\mathrm{Ha}$ & 72 & 36 & $10_{s}$ & 1.8 & 0.05 & - & 9 & - \\
\hline 17 & $\begin{array}{l}\text { Gás/solid high-temperature reaction } \\
\text { vessel }\end{array}$ & $\mathrm{Ha}$ & 72 & 36 & $10_{s}$ & 1.8 & 0.5 & - & 9 & - \\
\hline 18 & $\begin{array}{l}\text { Hydrogen gas (or ammonia) storage } \\
\text { tank }\end{array}$ & $\mathrm{Ha}$ & 72 & 36 & $10_{s}$ & 1.8 & 0.01 & - & 9 & - \\
\hline 19 & Stainless steel reaction vessel & $\mathrm{Ha}$ & 72 & 36 & $10_{s}$ & 1.8 & 0.5 & - & 9 & - \\
\hline 20 & Hydrogen fluoride storage tank & $\mathrm{Ha}$ & 72 & 36 & $10_{s}$ & 1.8 & 0.2 & - & 9 & - \\
\hline 21 & $\begin{array}{l}\text { Gas/solid ultrahigh temperature } \\
\text { reaction vessel }\end{array}$ & $\mathrm{Ha}$ & 72 & 36 & $10_{s}$ & 1.8 & 0.5 & - & 9 & - \\
\hline 22 & Fluorine storage tank & $\mathrm{Ha}$ & 72 & 36 & $10_{s}$ & 1.8 & 0.15 & - & 9 & - \\
\hline 23 & Hexafluoride condensing vessel & $\mathrm{Ha}$ & 72 & 36 & $10_{s}$ & 1.8 & 0.1 & - & 9 & - \\
\hline 24 & Pumps and piping & $\mathrm{Ha}$ & 72 & 36 & & 1.8 & 0.1 & - & 9 & - \\
\hline $10_{f}$ & Acquire FP components [finish] & - & - & & $11-24$ & - & - & - & - & - \\
\hline 25 & Assemble and integrate FP & $\mathrm{Fb}$ & 48 & 24 & $9,10 F F+12$ & 27.6 & - & 18 & 30 & 90 \\
\hline 26 & Operate FP. & LC & 120 & 60 & $5 S S+0,25$ & 590 & 4.0 & 42 & 240 & - \\
\hline$b_{f}$ & $\begin{array}{l}\text { Produce enrichment plant feed material } \\
\text { [finish] }\end{array}$ & - & - & - & $10_{f}, 26$ & & & - & - & - \\
\hline
\end{tabular}

(Continued on next page) 
Tasks involved in a nuclear weapons program. (Continued)

\begin{tabular}{|c|c|c|c|c|c|c|c|c|c|c|}
\hline ID & Name & Code & $\begin{array}{l}\text { Normal } \\
\text { duration } \\
\text { (wks) }\end{array}$ & $\begin{array}{l}\text { Crashed } \\
\text { duration } \\
\text { (wks) }\end{array}$ & Predecessors & $\begin{array}{l}\text { Energy } \\
\text { (MWhr) }\end{array}$ & $\begin{array}{c}\text { Materials } \\
\text { (\$M) }\end{array}$ & $\begin{array}{l}\text { Professional } \\
\text { labor } \\
(\mathrm{mm})\end{array}$ & $\begin{array}{l}\text { Skilled } \\
\text { labor } \\
(\mathrm{mm})\end{array}$ & $\begin{array}{l}\text { Unskilled } \\
\text { labor } \\
(\mathrm{mm})\end{array}$ \\
\hline$\overline{27 s}$ & $\begin{array}{l}\text { Enrich uranium [start] (some subset of } \\
\text { tasks 28--89) }\end{array}$ & - & - & - & $1_{\mathrm{s}}$ & - & - & - & - & - \\
\hline 28 & $\begin{array}{l}\text { Choose enrichment process (decision } \\
\text { node) }\end{array}$ & - & 0 & 0 & $27 s$ & - & - & - & - & - \\
\hline $29_{s}$ & $\begin{array}{l}\text { Gas centrifuge enrich-ment process (CP) } \\
\text { [start] (tasks 30-53) }\end{array}$ & 一 & - & - & 28 & - & 一 & 一 & 一 & 一 \\
\hline $\begin{array}{l}30 \\
31_{s}\end{array}$ & $\begin{array}{l}\text { Design basic GC } \\
\text { Acquire research components for CP } \\
\text { [start] (5 ea, tasks 32-37) }\end{array}$ & $\underline{\mathrm{Fb}}$ & $\underline{48}$ & 24 & $\begin{array}{l}29 s \\
30 S S+12\end{array}$ & $\stackrel{13.2}{-}$ & $\underline{0.2}$ & 36 & $\underline{30}$ & - \\
\hline 32 & Rotor tubes & $\mathrm{Fa}$ & 48 & 24 & 31 & 2.4 & 0.08 & 6 & 6 & - \\
\hline 33 & Air bearing systems & Ea & 40 & 20 & 31 & 1 & 0.08 & - & 5 & - \\
\hline 34 & Motors & Ea & 40 & 20 & 31 & 1 & 0.03 & - & 5 & - \\
\hline 35 & End caps & $\mathrm{Ca}$ & 24 & 12 & 31 & 0.6 & 0.03 & - & 3 & - \\
\hline 36 & Centrifuge cases & $\mathrm{Ca}$ & 24 & 12 & 31 & 0.6 & 0.05 & - & 3 & - \\
\hline 37 & Pumps and piping & $\mathrm{Ca}$ & 24 & 12 & 31 & 0.6 & 0.05 & - & 3 & - \\
\hline $31_{f}$ & $\begin{array}{l}\text { Acquire research components for CP } \\
\text { [finish] }\end{array}$ & - & - & - & $32-37$ & - & - & - & - & 一 \\
\hline 38 & Assemble research centrifuges & $\mathrm{Cb}$ & 24 & 12 & $29_{s} S S, 3 l_{f}$ & 9.6 & 0.1 & 18 & 30 & - \\
\hline 41 & Design enrichment cascade & $\mathrm{Db}$ & 32 & 16 & $40 S S+8$ & 12.8 & 0.07 & 24 & 40 & - \\
\hline 42 & Design enrichment plant (EP) & Eb & 40 & 20 & $41 S S+8$ & 16 & 0.08 & 30 & 50 & - \\
\hline 43 & Acquire EP site & $\mathrm{Ca}$ & 24 & 12 & $42 S S+4$ & 0.6 & 2.5 & 3 & - & - \\
\hline 44 & Prepare EP site & $\mathrm{Cc}$ & 24 & 12 & 43 & 13.2 & 0.3 & 3 & 30 & 30 \\
\hline $45_{s}$ & $\begin{array}{l}\text { Acquire production CP components } \\
\text { [start] (1000 ea, tasks 46-51) }\end{array}$ & - & - & - & $41 S S+8$ & - & - & - & 一 & - \\
\hline 46 & Rotor tubes & $\mathrm{Ja}$ & 96 & 48 & $45_{s}$ & 4.8 & 4.8 & 12 & 12 & - \\
\hline 47 & Air bearing systems & $\mathrm{Ja}$ & 96 & 48 & $45_{s}$ & 2.4 & 1.6 & - & 12 & - \\
\hline 48 & Motors & $\mathrm{Ja}$ & 96 & 48 & $45_{s}$ & 2.4 & 1.6 & - & 12 & - \\
\hline 49 & End caps & la & 80 & 40 & $45_{s}$ & 2.4 & 1.6 & - & 12 & - \\
\hline 50 & Centrifuge cases & la & 80 & 40 & $45_{s}$ & 2.4 & 3.2 & - & 12 & - \\
\hline 51 & Pumps and piping & la & 80 & 40 & $45_{s}$ & 2.4 & 3.2 & - & 12 & - \\
\hline $45_{f}$ & $\begin{array}{l}\text { Acquire production CP components } \\
\text { [finish] }\end{array}$ & - & 一 & 一 & $46-51$ & - & - & 一 & - & - \\
\hline 52 & Assemble production centrifuges & $\mathrm{Fb}$ & 48 & 24 & $29 \mathrm{SSS}, 44,45_{f} \mathrm{FF}+8$ & 315 & - & 42 & 1536 & - \\
\hline 53 & Integrate centrifuges & $\mathrm{Db}$ & 32 & 16 & $52 S S+8$ & 44 & - & 20 & 200 & - \\
\hline 54 & Cascade loading & $\mathrm{Kb}$ & 112 & 56 & $26 S S+8,52,53$ & 65 & - & 54 & 288 & - \\
\hline 55 & $\begin{array}{l}\text { Produce enriched and depleted } \\
\text { material }\end{array}$ & $\mathrm{Cc}$ & 24 & 12 & & 45,000 & - & 54 & 432 & 一 \\
\hline $29_{f}$ & $\begin{array}{l}\text { Gas centrifuge enrichment process (CP) } \\
\text { [finish] }\end{array}$ & - & - & - & $\begin{array}{l}55,45_{f}, 44,42,41 \\
40,31_{f}\end{array}$ & - & 一 & - & - & - \\
\hline
\end{tabular}




\begin{tabular}{|c|c|c|c|c|c|c|c|c|c|c|}
\hline ID & Name & Code & $\begin{array}{l}\text { Normal } \\
\text { duration } \\
\text { (wks) }\end{array}$ & $\begin{array}{c}\text { Crashed } \\
\text { duration } \\
\text { (wks) }\end{array}$ & Predecessors & $\begin{array}{l}\text { Energy } \\
\text { (MWhr) }\end{array}$ & $\begin{array}{l}\text { Materials } \\
\text { (\$M) }\end{array}$ & $\begin{array}{l}\text { Professional } \\
\text { labor } \\
\text { (mm) }\end{array}$ & $\begin{array}{l}\text { Skilled } \\
\text { labor } \\
(\mathrm{mm})\end{array}$ & $\begin{array}{l}\text { Unskilled } \\
\text { labor } \\
\text { (mm) }\end{array}$ \\
\hline$\overline{56}$ & $\begin{array}{l}\text { Gas-diffusion enrichment process (DP) } \\
\text { [start] (tasks } 57-76 \text { ) }\end{array}$ & - & 0 & 0 & 28 & - & - & - & - & - \\
\hline 57 & Design basic DP system & $\mathrm{Fb}$ & 48 & 24 & $566_{s}$ & 13.2 & 0.2 & 36 & 30 & - \\
\hline $58_{s}$ & $\begin{array}{l}\text { Acquire research components for DP } \\
\text { [start] (5 ea, tasks 59-61) }\end{array}$ & - & - & - & $57 S S+12$ & - & - & - & - & - \\
\hline 59 & Diffusion barriers & $\mathrm{Fa}$ & 48 & 24 & $58_{s}$ & 2.4 & 0.05 & 6 & 6 & - \\
\hline 60 & Heat exchangers & $\mathrm{Ea}$ & 40 & 20 & $58_{s}$ & 1 & 0.03 & - & 5 & - \\
\hline 61 & Pumps and piping & $\mathrm{Ca}$ & 24 & 12 & & 0.6 & 0.07 & - & 3 & - \\
\hline $58_{f}$ & $\begin{array}{l}\text { Acquire research components for DP } \\
\text { [finish] }\end{array}$ & - & - & - & $59-61$ & - & - & - & - & - \\
\hline 62 & Assemble research devices & $\mathrm{Cb}$ & 24 & 12 & $58{ }_{f} \mathrm{FF}, 56_{\mathrm{s}}$ & 9.6 & 0.1 & 18 & 30 & - \\
\hline 63 & Test and evaluate research devices & $\mathrm{Cb}$ & 24 & 12 & & 9.6 & 0.1 & 18 & 30 & - \\
\hline 64 & $\begin{array}{l}\text { Design production gas-diffusion } \\
\text { devices }\end{array}$ & $\mathrm{Db}$ & 32 & 16 & $63 \mathrm{FS}-4$ & 8.8 & 0.07 & 24 & 20 & - \\
\hline 65 & Design enrichment cascade & $\mathrm{Db}$ & 32 & 16 & $64 S S+8$ & 12.8 & 0.07 & 24 & 40 & - \\
\hline 66 & Design enrichment plant (EP) & $\mathrm{Eb}$ & 40 & 20 & $65 S S+8$ & 16 & 0.08 & 30 & 50 & - \\
\hline 67 & Acquire EP site & $\mathrm{Ca}$ & 24 & 12 & $66 S S+4$ & 0.6 & 5 & 3 & - & - \\
\hline 68 & Prepare EP site & $\mathrm{Cc}$ & 24 & 12 & & 13.2 & 0.55 & 3 & 30 & 30 \\
\hline $69 \mathrm{~s}$ & $\begin{array}{l}\text { Acquire production components for DP } \\
\text { [start] (4000 ea, tasks } 70-72)\end{array}$ & - & - & - & $65 S S+8$ & - & - & - & - & - \\
\hline 70 & Diffusion barriers & $\mathrm{Fa}$ & 48 & 24 & 69 & 2.4 & 40 & 6 & 6 & - \\
\hline 71 & Heat exchangers & Ea & 40 & 20 & 69 & 1 & 20 & - & 5 & - \\
\hline 72 & Pumps and piping & $\mathrm{Ca}$ & 24 & 12 & 69 & 0.8 & 60 & - & 4 & - \\
\hline $69_{f}$ & $\begin{array}{l}\text { Acquire production components for DP } \\
\text { [finish] }\end{array}$ & - & - & - & $70-72$ & - & - & - & - & - \\
\hline 73 & Assemble production devices for DP & $\mathrm{Fb}$ & 48 & 24 & $68,69 \mathrm{fF}+8$ & 126 & - & 30 & 600 & - \\
\hline 74 & Integrate enrichment cascade & $\mathrm{Db}$ & 32 & 16 & $73 S S+8$ & 84 & - & 20 & 400 & - \\
\hline 75 & Cascade loading & $\mathrm{Kb}$ & 112 & 56 & $26 S S+8,73,74$ & 65 & - & 36 & 288 & - \\
\hline 76 & $\begin{array}{l}\text { Produce enriched and depleted } \\
\text { material }\end{array}$ & $\mathrm{Cc}$ & 24 & 12 & & 600,000 & - & 54 & 432 & - \\
\hline $56_{f}$ & $\begin{array}{l}\text { Gas-diffusion enrichment process (DP) } \\
\text { [finish] }\end{array}$ & - & - & - & $76,64-66,58_{f}, 57$ & - & - & - & - & - \\
\hline $77_{s}$ & $\begin{array}{l}\text { Aerodynamic enrichment process (AP) } \\
\text { [start] (tasks 78-95) }\end{array}$ & - & 0 & 0 & 28 & - & - & - & - & - \\
\hline 78 & Design basic AP enrichment device & $\mathrm{Fb}$ & 48 & 24 & $77 \mathrm{~s}$ & 13.2 & 0.2 & 36 & 30 & - \\
\hline $79_{\mathrm{s}}$ & $\begin{array}{l}\text { Acquire research components for AP } \\
\text { [start] (5 ea, tasks } 80-81 \text { ) }\end{array}$ & - & - & - & $78 S S+12$ & - & - & - & - & - \\
\hline 80 & Vortex unit & $\mathrm{Fa}$ & 48 & 24 & $79 \mathrm{~s}$ & 2.4 & 0.25 & 6 & 6 & - \\
\hline 81 & Pumps and piping & $\mathrm{Ca}$ & 24 & 12 & $79 \mathrm{~s}$ & 0.6 & 0.08 & - & 3 & - \\
\hline $79_{f}$ & $\begin{array}{l}\text { Acquire research components for AP } \\
\text { [finish] }\end{array}$ & - & - & - & 80,81 & - & - & - & - & - \\
\hline 82 & Assemble research devices & $\mathrm{Cb}$ & 24 & 12 & $79_{f}$ & 9.6 & 0.1 & 18 & 30 & - \\
\hline
\end{tabular}


Tasks involved in a nuclear weapons program. (Continued)

\begin{tabular}{|c|c|c|c|c|c|c|c|c|c|c|}
\hline ID & Name & Code & $\begin{array}{c}\text { Normal } \\
\text { duration } \\
\text { (wks) }\end{array}$ & $\begin{array}{l}\text { Crashed } \\
\text { duration } \\
\text { (wks) }\end{array}$ & Predecessors & $\begin{array}{l}\text { Energy } \\
\text { (MWhr) }\end{array}$ & $\begin{array}{c}\text { Materials } \\
(\$ M)\end{array}$ & $\begin{array}{l}\text { Professional } \\
\text { labor } \\
(\mathrm{mm})\end{array}$ & $\begin{array}{l}\text { Skilled } \\
\text { labor } \\
(\mathrm{mm})\end{array}$ & $\begin{array}{c}\text { Unskilled } \\
\text { labor } \\
(\mathrm{mm})\end{array}$ \\
\hline$\overline{83}$ & Test and evaluate research devices & $\mathrm{Cb}$ & 24 & 12 & 82 & 9.6 & 0.1 & 18 & 30 & - \\
\hline 84 & Design production devices & $\mathrm{Db}$ & 32 & 16 & $83 F S-4$ & 8.8 & 0.07 & 24 & 20 & - \\
\hline 85 & Design enrichment cascade & $\mathrm{Db}$ & 32 & 16 & $84 S S+8$ & 12.8 & 0.07 & 24 & 40 & - \\
\hline 86 & Design of enrichment plant (EP) & $\mathrm{Eb}$ & 40 & 20 & $85 S S+8$ & 16 & 0.08 & 30 & 50 & - \\
\hline 87 & Acquire EP site & $\mathrm{Ca}$ & 24 & 12 & $86 S S+4$ & 0.6 & 2 & 3 & - & - \\
\hline 88 & Prepare EP site & $\mathrm{Cc}$ & 24 & 12 & & 12.6 & 0.25 & 3 & 30 & 30 \\
\hline $89_{s}$ & $\begin{array}{l}\text { Acquire production components for AP } \\
\text { [start] }(600 \text { ea, tasks } 90-91)\end{array}$ & - & - & - & $85 S S+8$ & - & - & - & - & - \\
\hline 90 & Vortex unit & $\mathrm{Fa}$ & 48 & 24 & $89 s$ & 2.4 & 30 & 6 & 6 & - \\
\hline 91 & Pumps and piping & la & 80 & 40 & $89_{s}^{\circ}$ & 1.2 & 9 & - & 6 & - \\
\hline $89_{f}$ & $\begin{array}{l}\text { Acquire production components for AP } \\
\text { [finish] }\end{array}$ & - & - & - & 90,91 & - & - & - & 一 & - \\
\hline 92 & Assemble production devices & $\mathrm{Fb}$ & 48 & 24 & $88,89_{f} \mathrm{FF}+8$ & 126 & - & 30 & 600 & - \\
\hline 93 & Integrate enrichment cascade & $\mathrm{Db}$ & 32 & 16 & $92 S S+8$ & 84 & - & 20 & 400 & - \\
\hline 94 & Cascade loading & $\mathrm{Kb}$ & 112 & 56 & $26 S S+8,92,93$ & 65 & - & 36 & 288 & - \\
\hline 95 & $\begin{array}{l}\text { Produce enriched and depleted } \\
\text { material }\end{array}$ & $\mathrm{Cc}$ & 24 & 12 & 94 & 900,000 & - & 54 & 432 & - \\
\hline $77_{f}$ & $\begin{array}{l}\text { Aerodynamic enrichment process (AP) } \\
\text { [finish] }\end{array}$ & - & - & - & $93,92,84-86,79 f, 78$ & - & - & - & - & - \\
\hline $27_{f}$ & Enrich uranium [finish] & 一 & - & - & 28,95 & 一 & - & - & 一 & - \\
\hline $96 s$ & $\begin{array}{l}\text { Prepare uranium metal [start] (tasks } \\
97-112 \text { ) }\end{array}$ & - & - & - & $1_{\mathrm{s}}$ & - & - & - & - & - \\
\hline 97 & Design metal plant (MP) & $\mathrm{Gb}$ & 56 & 28 & $96 s$ & 19.6 & 0.12 & 28 & 70 & - \\
\hline 98 & Acquire MP site & $\mathrm{Ca}$ & 24 & 12 & $97 S S+12$ & 0.6 & 0.1 & 3 & - & - \\
\hline 99 & Prepare MP site & $\mathrm{Cc}$ & 24 & 12 & & 6.6 & 0.06 & 3 & 15 & 15 \\
\hline $100_{s}$ & $\begin{array}{l}\text { Acquire metal plant components [start] } \\
\text { (enriched metal, tasks 101-104) }\end{array}$ & - & - & - & $96_{s}$ & - & - & - & 一 & - \\
\hline 101 & $\begin{array}{l}\text { Gas-phase reactor with particulate } \\
\text { collection }\end{array}$ & $\mathrm{Fa}$ & 48 & 24 & $96_{s}$ & 1.8 & 0.25 & 6 & 3 & - \\
\hline 102 & Hydrogen storage tank & $\mathrm{Fa}$ & 48 & 24 & $96 s$ & 0.6 & 0.001 & - & 3 & - \\
\hline 103 & Metallurgical furnace & $\mathrm{Fa}$ & 48 & 24 & $96 \mathrm{~s}$ & 0.6 & 0.1 & - & 3 & - \\
\hline 104 & Hafnia crucibles & $\mathrm{Fa}$ & 48 & 24 & $96 \mathrm{~s}$ & 0.6 & 0.03 & - & 3 & - \\
\hline $100_{f}$ & $\begin{array}{l}\text { Acquire metal plant components, } \\
\text { enriched metal [finish] }\end{array}$ & - & - & - & $101-104$ & - & - & - & 一 & - \\
\hline $105_{s}$ & $\begin{array}{l}\text { Acquire metal plant components, } \\
\text { depleted metal [start] (tasks 104-109) }\end{array}$ & - & - & - & $96_{s}$ & - & - & - & - & - \\
\hline 106 & $\begin{array}{l}\text { Gas-phase reactor with particulate } \\
\text { collection }\end{array}$ & $\mathrm{Fa}$ & 48 & 24 & $105_{s}$ & 0.6 & 0.25 & - & 3 & - \\
\hline 107 & Hydrogen storage tank & $\mathrm{Fa}$ & 48 & 24 & $105_{s}$ & 0.6 & 0.001 & - & 3 & - \\
\hline
\end{tabular}




\begin{tabular}{|c|c|c|c|c|c|c|c|c|c|c|}
\hline ID & Name & Code & $\begin{array}{c}\text { Normal } \\
\text { duration } \\
\text { (wks) }\end{array}$ & $\begin{array}{l}\text { Crashed } \\
\text { duration } \\
\text { (wks) }\end{array}$ & Predecessors & $\begin{array}{l}\text { Energy } \\
\text { (MWhr) }\end{array}$ & $\begin{array}{l}\text { Materials } \\
\text { (\$M) }\end{array}$ & $\begin{array}{l}\text { Professional } \\
\text { labor } \\
(\mathrm{mm})\end{array}$ & $\begin{array}{l}\text { Skilled } \\
\text { labor } \\
(\mathrm{mm})\end{array}$ & $\begin{array}{l}\text { Unskilled } \\
\text { labor } \\
(\mathrm{mm})\end{array}$ \\
\hline 108 & Metallurgical furnace & $\mathrm{Fa}$ & 48 & 24 & $105_{\mathrm{s}}$ & 0.6 & 0.1 & - & 3 & - \\
\hline $\begin{array}{l}109 \\
105_{f}\end{array}$ & $\begin{array}{l}\text { Hafnia crucibles } \\
\text { Acquire metal plant components, }\end{array}$ & $\underline{\mathrm{Fa}}$ & $\underline{48}$ & 24 & $\begin{array}{l}105_{s} \\
106-109\end{array}$ & $\underline{0.6}$ & 0.03 & - & $\underline{3}$ & - \\
\hline 110 & Integrate components & $\mathrm{Db}$ & 32 & 16 & $99,100 \mathrm{FF}+12,105 \mathrm{FF}$ & 20.8 & - & 24 & 40 & 40 \\
\hline $\begin{array}{l}111 \\
112\end{array}$ & $\begin{array}{l}\text { Produce natural uranium metal } \\
\text { Produce depleted/enriched uranium }\end{array}$ & $\begin{array}{l}\mathrm{Fc} \\
\mathrm{Cc}\end{array}$ & $\begin{array}{l}48 \\
24\end{array}$ & $\begin{array}{l}24 \\
12\end{array}$ & $\begin{array}{l}110 \\
27_{\mathrm{f} F F}\end{array}$ & $\begin{array}{r}80 \\
160\end{array}$ & $\begin{array}{l}0.01 \\
0.02\end{array}$ & $\begin{array}{r}6 \\
12\end{array}$ & $\begin{array}{l}18 \\
36\end{array}$ & - \\
\hline $\begin{array}{l}966_{f} \\
113_{s}\end{array}$ & $\begin{array}{l}\text { Prepare uranium metal [finish] } \\
\text { Prepare nuclear explosive devices [start] } \\
\text { (tasks nulds-196) }\end{array}$ & 二 & $\overline{-}$ & $\overline{-}$ & $\begin{array}{l}97,112 \\
1_{s}\end{array}$ & $\overline{-}$ & 二 & - & - & - \\
\hline $114_{s}$ & $\begin{array}{l}\text { Design gun device components [start] } \\
\text { (tasks 115-123) }\end{array}$ & - & - & - & $113_{s}$ & - & - & - & - & - \\
\hline $\begin{array}{l}115 \\
116\end{array}$ & $\begin{array}{l}\text { Gun } \\
\text { Propellant }\end{array}$ & $\begin{array}{l}\mathrm{Fb} \\
\mathrm{Fb}\end{array}$ & $\begin{array}{l}48 \\
48\end{array}$ & $\begin{array}{l}24 \\
24\end{array}$ & $\begin{array}{l}114_{s} \\
114_{s}\end{array}$ & $\begin{array}{l}9.6 \\
3.6\end{array}$ & $\begin{array}{l}0.2 \\
0.03\end{array}$ & $\begin{array}{r}18 \\
6\end{array}$ & $\begin{array}{l}30 \\
12\end{array}$ & - \\
\hline $117 \mathrm{~s}$ & Critical core [start] (tasks 118-121) & & & & $114_{s}^{s}$ & - & & & & - \\
\hline $\begin{array}{l}118 \\
119 \\
120\end{array}$ & $\begin{array}{l}\text { Fissionable receiver } \\
\text { Fissionable projectile }\end{array}$ & $\begin{array}{l}\mathrm{Fb} \\
\mathrm{Fb}\end{array}$ & $\begin{array}{l}48 \\
48 \\
\end{array}$ & $\begin{array}{l}24 \\
24\end{array}$ & $\begin{array}{l}117 \mathrm{~s} \\
117_{s}\end{array}$ & $\begin{array}{l}9.6 \\
9.6 \\
0.6\end{array}$ & $\begin{array}{l}0.07 \\
0.05 \\
0.05\end{array}$ & $\begin{array}{l}18 \\
18\end{array}$ & $\begin{array}{l}30 \\
30\end{array}$ & 二 \\
\hline 121 & $\begin{array}{l}\text { lamper } \\
\text { Initiator }\end{array}$ & $\begin{array}{l}\mathrm{FD} \\
\mathrm{Fb}\end{array}$ & $\begin{array}{l}48 \\
48\end{array}$ & $\begin{array}{l}24 \\
24\end{array}$ & $117 \mathrm{~s}$ & $\begin{array}{l}1.0 \\
1.2\end{array}$ & 0.01 & $\begin{array}{r}18 \\
6\end{array}$ & $\underline{30}$ & 二 \\
\hline $117_{\mathrm{f}}$ & Critical core [finish] & - & - & - & $118-121$ & - & - & - & - & - \\
\hline $\begin{array}{l}122 \\
123\end{array}$ & $\begin{array}{l}\text { Safety and arming devices } \\
\text { Fuse }\end{array}$ & $\begin{array}{l}\mathrm{Fb} \\
\mathrm{Fb}\end{array}$ & $\begin{array}{l}48 \\
48\end{array}$ & $\begin{array}{l}24 \\
24\end{array}$ & $\begin{array}{l}114_{s} \\
114_{s}\end{array}$ & $\begin{array}{l}2.4 \\
2.4\end{array}$ & $\begin{array}{l}0.01 \\
0.01\end{array}$ & $\begin{array}{l}6 \\
6\end{array}$ & $\begin{array}{l}6 \\
6\end{array}$ & $\bar{z}$ \\
\hline $114_{f}$ & Design gun device components [finish] & - & - & - & $\begin{array}{l}115,116,117 f, 122, \\
123\end{array}$ & - & - & - & - & - \\
\hline $\begin{array}{l}124 \\
125\end{array}$ & $\begin{array}{l}\text { Design weapon assembly plant (AP) } \\
\text { Acquire AP site }\end{array}$ & $\begin{array}{l}\mathrm{Cb} \\
\mathrm{Ba}\end{array}$ & $\begin{array}{l}24 \\
16\end{array}$ & $\begin{array}{r}12 \\
8\end{array}$ & $\begin{array}{l}114_{f} \\
124\end{array}$ & $\begin{array}{l}12 \\
0.6\end{array}$ & $\begin{array}{l}0.07 \\
0.8\end{array}$ & $\begin{array}{r}30 \\
3\end{array}$ & 30 & - \\
\hline 126 & Prepare AP site & $\mathrm{Cc}$ & 24 & 12 & 125 & 6.6 & 0.15 & 3 & 15 & 15 \\
\hline $127 \mathrm{~s}$ & $\begin{array}{l}\text { Acquire fabrication devices [start] (tasks } \\
\text { 128-132) }\end{array}$ & - & - & - & $114_{f}$ & - & - & - & - & - \\
\hline $\begin{array}{l}128 \\
129\end{array}$ & $\begin{array}{l}\text { Large-diameter precision lathe } \\
\text { Inert-gas environment precision } \\
\text { milling machine }\end{array}$ & $\begin{array}{l}\mathrm{Fa} \\
\mathrm{Fa}\end{array}$ & $\begin{array}{l}48 \\
48\end{array}$ & $\begin{array}{l}24 \\
24\end{array}$ & $\begin{array}{l}126 \mathrm{FF}+12 \\
126 \mathrm{FF}+12\end{array}$ & $\begin{array}{l}2.4 \\
1.2\end{array}$ & $\begin{array}{l}0.1 \\
0.25\end{array}$ & $\underline{6}$ & $\begin{array}{l}6 \\
6\end{array}$ & 二 \\
\hline $\begin{array}{l}130 \\
131\end{array}$ & $\begin{array}{l}\text { Metallurgical furnace } \\
\text { Hafnia crucibles }\end{array}$ & $\begin{array}{l}\mathrm{Fa} \\
\mathrm{Fa}\end{array}$ & $\begin{array}{l}48 \\
48\end{array}$ & 24 & $\begin{array}{l}126 \mathrm{FF}+12 \\
126 \mathrm{FF}+12\end{array}$ & 1.2 & $\begin{array}{l}0.25 \\
0.05\end{array}$ & $\overline{-}$ & $\begin{array}{l}6 \\
6\end{array}$ & - \\
\hline 132 & Inert-gas environment casting system & $\mathrm{Fa}$ & 48 & 24 & $126 \mathrm{FF}+12$ & 1.2 & 0.05 & - & 6 & - \\
\hline
\end{tabular}


Tasks involved in a nuclear weapons program. (Continued)

\begin{tabular}{|c|c|c|c|c|c|c|c|c|c|c|}
\hline$\underline{\text { ID }}$ & Name & Code & $\begin{array}{c}\text { Normal } \\
\text { duration } \\
\text { (wks) }\end{array}$ & $\begin{array}{c}\text { Crashed } \\
\text { duration } \\
\text { (wks) }\end{array}$ & Predecessors & $\begin{array}{l}\text { Energy } \\
\text { (MWhr) }\end{array}$ & $\begin{array}{l}\text { Materials } \\
(\$ M)\end{array}$ & $\begin{array}{l}\text { Professional } \\
\text { labor } \\
(\mathrm{mm})\end{array}$ & $\begin{array}{l}\text { Skilled } \\
\text { labor } \\
(\mathrm{mm})\end{array}$ & $\begin{array}{l}\text { Unskillec } \\
\text { labor } \\
(\mathrm{mm})\end{array}$ \\
\hline $127_{f}$ & Acquire fabrication devices [finish] & - & - & - & $128-132$ & - & - & - & - & - \\
\hline $133_{s}$ & $\begin{array}{l}\text { Acquire research device components } \\
\text { [start] (natural uranium prototype, } \\
\text { tasks 134-138) }\end{array}$ & - & - & - & 114 & - & - & - & - & - \\
\hline 134 & High-strength steel cylinder & $\mathrm{Ca}$ & 24 & 12 & $133_{s}$ & 0.6 & 0.01 & - & 3 & - \\
\hline 135 & Double-base propellant powder & $\mathrm{Ca}$ & 24 & 12 & $133_{s}$ & 0.6 & 0.01 & - & 3 & - \\
\hline 136 & Polonium & $\mathrm{Ca}$ & 24 & 12 & $133_{s}$ & 0.6 & 0.05 & - & 3 & - \\
\hline 137 & Beryllium powder & $\mathrm{Ca}$ & 24 & 12 & $133_{s}$ & 0.6 & 0.01 & - & 3 & - \\
\hline 138 & $\begin{array}{l}\text { Detonator and explosive train } \\
\text { components }\end{array}$ & $\mathrm{Ca}$ & 24 & 12 & $133_{s}$ & 0.6 & 0.01 & - & 3 & - \\
\hline $133_{f}$ & $\begin{array}{l}\text { Acquire research device components } \\
\text { [finish] (natural uranium prototype) }\end{array}$ & - & - & - & $134-138$ & - & - & - & - & - \\
\hline $139_{s}$ & $\begin{array}{l}\text { Fabricate research device components } \\
\text { [start] (natural uranium prototype, } \\
\text { tasks 140-149) }\end{array}$ & - & - & - & $133_{f}, 139_{s}$ & - & - & - & - & - \\
\hline 140 & Gun barrel & Fc & 48 & 24 & $128,135,139_{s}$ & 3.6 & - & 9 & 9 & - \\
\hline 141 & Breech mechanism & Fc & 48 & 24 & $128,135,139 \mathrm{~s}$ & 1.8 & - & - & 9 & - \\
\hline 142 & Cast uranium components & Dc & 32 & 16 & $111,130,139 s$ & 16 & - & - & 6 & - \\
\hline 143 & Cast uranium tamper & Dc & 32 & 16 & $111,130,139 s$ & 16 & - & - & 6 & - \\
\hline 144 & Machine uranium receiver & Dc & 32 & 16 & $129,142 \mathrm{FF}+8,139 \mathrm{~s}$ & 1.2 & - & - & 6 & - \\
\hline 145 & Machine uranium projectile & Dc & 32 & 16 & $129,142 \mathrm{FF}+8,139 \mathrm{~s}$ & 1.2 & - & - & 6 & - \\
\hline 146 & Machine uranium tamper & Dc & 32 & 16 & $129,142 \mathrm{FF}+8,139_{s}$ & 1.2 & - & - & 6 & - \\
\hline 147 & Initiator & Dc & 32 & 16 & $131,136,137,139 s$ & 2.4 & - & 6 & 6 & - \\
\hline 148 & Propellant charge & Dc & 32 & 16 & $132,135,139 s$ & 1.2 & - & - & 6 & - \\
\hline 149 & Detonator and explosive train & $\mathrm{Db}$ & 32 & 16 & $138,139 s$ & 1.2 & - & 一 & 6 & - \\
\hline $139_{f}$ & $\begin{array}{l}\text { Fabricate research device components } \\
\text { [finish] }\end{array}$ & - & - & - & $140-149$ & - & - & - & - & - \\
\hline 150 & $\begin{array}{l}\text { Assemble research devices (natural } \\
\text { uranium prototype) }\end{array}$ & Dc & 32 & 16 & $\underset{4}{133_{f} F F}+4,139_{f} F F+$ & 3.6 & - & 6 & 12 & - \\
\hline $151_{s}$ & $\begin{array}{l}\text { Acquire research device components } \\
\text { [start] (enriched uranium prototype, } \\
\text { tasks 152--157) }\end{array}$ & - & 0 & 0 & 172 & - & - & - & - & - \\
\hline 152 & High-strength steel cylinder & $\mathrm{Ca}$ & 24 & 12 & $151_{s}$ & 0.6 & 0.01 & 一 & 3 & - \\
\hline 153 & Double-base propellant powder & $\mathrm{Ca}$ & 24 & 12 & $151_{s}$ & 0.6 & 0.01 & - & 3 & - \\
\hline 154 & Polonium & $\mathrm{Ca}$ & 24 & 12 & $151_{s}$ & 0.6 & 0.05 & - & 3 & - \\
\hline 155 & Beryllium powder & $\mathrm{Ca}$ & 24 & 12 & $151_{s}$ & 0.6 & 0.01 & - & 3 & - \\
\hline 156 & $\begin{array}{l}\text { Detonator and explosive train } \\
\text { components }\end{array}$ & $\mathrm{Ca}$ & 24 & 12 & $151_{s}$ & 0.6 & 0.01 & - & 3 & - \\
\hline $15 l_{f}$ & $\begin{array}{l}\text { Acquire research device components } \\
\text { [finish] }\end{array}$ & - & - & - & $152-156$ & - & - & - & - & - \\
\hline
\end{tabular}




\begin{tabular}{|c|c|c|c|c|c|c|c|c|c|c|}
\hline ID & Name & Code & $\begin{array}{c}\text { Normal } \\
\text { duration } \\
\text { (wks) }\end{array}$ & $\begin{array}{c}\text { Crashed } \\
\text { duration } \\
\text { (wks) }\end{array}$ & Predecessors & $\begin{array}{l}\text { Energy } \\
\text { (MWhr) }\end{array}$ & $\begin{array}{c}\text { Materials } \\
(\$ M)\end{array}$ & $\begin{array}{c}\text { Professional } \\
\text { labor } \\
(\mathrm{mm}) \\
\end{array}$ & $\begin{array}{l}\text { Skilled } \\
\text { labor } \\
(\mathrm{mm})\end{array}$ & $\begin{array}{c}\text { Unskilled } \\
\text { labor } \\
(\mathrm{mm})\end{array}$ \\
\hline$\overline{157 s}$ & $\begin{array}{l}\text { Fabricate research device components, } \\
\text { enriched uranium prototype [start] } \\
\text { (tasks } 158-167 \text { ) }\end{array}$ & - & 0 & 0 & 172 & - & - & - & - & - \\
\hline 158 & Gun barrel & $\mathrm{Cc}$ & 24 & 12 & $128,152,157_{\mathrm{s}}$ & 3.6 & - & 9 & 9 & - \\
\hline 159 & Breech mechanism & $\mathrm{Cc}$ & 24 & 12 & $128,129,157_{s}$ & 1.8 & - & - & 9 & - \\
\hline 160 & Casting of enriched uranium & Ac & 8 & 4 & $112,130,157_{\mathrm{s}}^{\mathrm{s}}$ & 16 & - & - & 6 & - \\
\hline 161 & $\begin{array}{l}\text { Components } \\
\text { Cast depleted uranium tamper }\end{array}$ & $A c$ & 8 & 4 & $112,130,157 \mathrm{~s}$ & 16 & - & - & 6 & - \\
\hline 162 & Machine enriched uranium receiver & $\mathrm{BC}$ & 16 & 8 & $129,160,157_{\mathrm{s}}^{\mathrm{s}}$ & 1.2 & - & - & 6 & - \\
\hline 163 & Machine enriched uranium projectile & $\mathrm{BC}$ & 16 & 8 & $129,160,157_{\mathrm{s}}$ & 1.2 & - & - & 6 & - \\
\hline 164 & Machine depleted uranium tamper & $\mathrm{BC}$ & 16 & 8 & $129,161,157_{\mathrm{s}}^{\mathrm{s}}$ & 1.2 & - & - & 6 & - \\
\hline 165 & Initiator & Ac & 8 & 4 & $131,154,155,157_{s}$ & 2.4 & - & 6 & 6 & - \\
\hline 166 & Propellant charge & Ac & 8 & 4 & $132,153,157_{s}$ & 1.2 & - & - & 6 & - \\
\hline 167 & Detonator and explosive train & Ac & 8 & 4 & $156,157 \mathrm{~s}$ & 1.2 & - & - & 6 & - \\
\hline $157_{f}$ & $\begin{array}{l}\text { Fabricate research device components, } \\
\text { enriched uranium prototype Ifinishl }\end{array}$ & - & - & - & $158-167$ & - & - & - & - & - \\
\hline 168 & Assemble research devices (enriched & $\mathrm{Ab}$ & 16 & 8 & $151 \mathrm{FF}+4$ & 3.6 & - & 6 & 12 & - \\
\hline 169 s & $\begin{array}{l}\text { Sub-critical testing of research devices } \\
\text { [start] (tasks } 170-174 \text { ) }\end{array}$ & - & - & - & $170-172$ & - & - & - & - & - \\
\hline 170 & Verify critical mass & $\mathrm{Cb}$ & 24 & 12 & $170 F F+4$ & 2.4 & - & 6 & 6 & - \\
\hline 171 & Verify gun velocity & $\mathrm{Cb}$ & 24 & 12 & 160 & 3.6 & $0 . \overline{1}$ & 6 & 12 & - \\
\hline 172 & Delivery vehicle compatibility mock-up & $\mathrm{Cb}$ & 24 & 12 & & 3.6 & 0.1 & 6 & 12 & - \\
\hline $169_{f}$ & $\begin{array}{l}\text { Sub-critical testing of research devices } \\
\text { [finish] }\end{array}$ & - & - & - & 170,172 & - & - & - & - & - \\
\hline 173 & Test full-scale device (not required) & $\mathrm{Fb}$ & 48 & 24 & 170 & 80 & 1 & 36 & 360 & - \\
\hline 174 & Finalize production-weapon design & $\mathrm{Eb}$ & 40 & 20 & $170 F F+12$ & 18 & 0.1 & 30 & 60 & 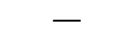 \\
\hline 175 & Acquire weapon components [start] & - & - & - & $174 S S+8$ & - & - & - & - & - \\
\hline 176 & High-strength steel cylinder & $\mathrm{Ca}$ & 24 & 12 & $175_{s}$ & 1.2 & 0.06 & - & 6 & - \\
\hline 177 & Double-base propellant powder & $\mathrm{Ca}$ & 24 & 12 & $175_{s}^{s}$ & 1.2 & 0.06 & - & 6 & - \\
\hline 178 & Polonium & $\mathrm{Ca}$ & 24 & 12 & $175_{s}$ & 1.2 & 0.3 & - & 6 & - \\
\hline 179 & Beryllium powder & $\mathrm{Ca}$ & 24 & 12 & $175_{s}^{\circ}$ & 1.2 & 0.06 & - & 6 & - \\
\hline 180 & Detonator and explosive train & $\mathrm{Ca}$ & 24 & 12 & $175_{s}^{s}$ & 1.2 & 0.06 & - & 6 & - \\
\hline \multirow{3}{*}{$\begin{array}{l}175_{f} \\
181_{s}\end{array}$} & \multirow{3}{*}{$\begin{array}{l}\text { Acquire weapon components [finish] } \\
\text { Fabricate weapon components [start] } \\
\text { (tasks 182-194) }\end{array}$} & - & - & - & $176-180$ & - & - & - & - & - \\
\hline & & - & - & - & 174 & - & - & - & - & - \\
\hline & & & & & & & & & \multicolumn{2}{|c|}{ (Contin } \\
\hline
\end{tabular}


Tasks involved in a nuclear weapons program. (Continued)

\begin{tabular}{|c|c|c|c|c|c|c|c|c|c|c|}
\hline ID & Name & Code & $\begin{array}{l}\text { Normal } \\
\text { duration } \\
\text { (wks) }\end{array}$ & $\begin{array}{l}\text { Crashed } \\
\text { duration } \\
\text { (wks) }\end{array}$ & Predecessors & $\begin{array}{l}\text { Energy } \\
\text { (MWhr) }\end{array}$ & $\begin{array}{l}\text { Materials } \\
\text { (\$M) }\end{array}$ & $\begin{array}{l}\text { Professional } \\
\text { labor } \\
(\mathrm{mm})\end{array}$ & $\begin{array}{l}\text { Skilled } \\
\text { labor } \\
(\mathrm{mm})\end{array}$ & $\begin{array}{l}\text { Unskilled } \\
\text { labor } \\
\text { (mm) }\end{array}$ \\
\hline 182 & Gun barrel & $\mathrm{Cc}$ & 24 & 12 & $128,176,181_{s}$ & 4.8 & - & 12 & 12 & - \\
\hline 183 & Breech mechanism & $\mathrm{Cc}$ & 24 & 12 & $128,129,181_{s}$ & 2.4 & - & - & 12 & - \\
\hline 184 & Cast enriched uranium components & $\mathrm{Cc}$ & 24 & 12 & $112,130,181_{s}$ & 93 & - & - & 12 & - \\
\hline 185 & Cast depleted uranium tamper & $\mathrm{Cc}$ & 24 & 12 & 112,130 & 93 & - & - & 12 & - \\
\hline 186 & Machine enriched uranium receiver & $\mathrm{Cc}$ & 24 & 12 & D & 2.4 & - & - & 12 & - \\
\hline 187 & Machine enriched uranium projectile & $\mathrm{Cc}$ & 24 & 12 & 125,180 & 2.4 & - & - & $1 \overline{2}$ & - \\
\hline 188 & Machine depleted uranium tamper & $\mathrm{Cc}$ & 24 & 12 & 129,185 & 2.4 & - & - & 12 & - \\
\hline 189 & Initiator & $\mathrm{Cc}$ & 24 & 12 & $131,178,179,181_{\mathrm{s}}$ & 4.8 & - & 12 & 12 & - \\
\hline 190 & Propellant charge & $\mathrm{Cc}$ & 24 & 12 & $132,177,181_{s}$ & 2.4 & - & - & 12 & - \\
\hline 191 & Detonator and explosive train & $\mathrm{Cc}$ & 24 & 12 & $180,181_{s}$ & 2.4 & - & - & 12 & - \\
\hline 192 & Fuse & $\mathrm{Cc}$ & 24 & 12 & $181_{s}$ & 2.4 & - & - & 12 & - \\
\hline 193 & Safety and arming device & $\mathrm{Cc}$ & 24 & 12 & $181_{s}$ & 2.4 & - & - & 12 & - \\
\hline 194 & Weapon case and structure & $\mathrm{Cc}$ & 24 & 12 & $172,181_{\mathrm{s}}$ & 2.4 & - & - & 12 & - \\
\hline $18 l_{f}$ & Fabricate weapon components [finish] & - & - & - & $182-183,186-194$ & - & - & - & - & - \\
\hline 195 & Assemble weapon components & $\mathrm{Cc}$ & 24 & 12 & $18 l_{f}$ & 7.2 & 0.1 & 12 & 24 & - \\
\hline 196 & Production weapons deliveries & - & 0 & 0 & 195 & - & - & - & - & - \\
\hline $113_{f}$ & Prepare nuclear explosive devices [finish] & - & - & — & 196 & - & - & - & - & - \\
\hline$l_{f}$ & NUCLEAR WEAPONS PROGRAM (finish) & - & 0 & 0 & $113_{f}$ & - & - & - & - & - \\
\hline
\end{tabular}

Source: the authors. 